\title{
Banks of algal microscopic forms: hypotheses on their functioning and comparisons with seed banks
}

\author{
Alicia J. Hoffmann, Bernabé Santelices \\ Departamento de Ecología, Facultad de Ciencias Biológicas, Pontificia Universidad Católica de Chile, \\ Casilla 114-D, Santiago, Chile
}

\begin{abstract}
It has been proposed that a 'bank of microscopic forms' functions as a survival mechanism for benthic macroalgae, in some ways analogous to the 'seed bank' of terrestrial plants. Four aspects related to this hypothesis are examined here, namely (1) origin and morphology of the structures forming banks; (2) their specific compositions; (3) environmental conditions that allow their survival in a state of suspended growth, and conditions that trigger reinitiation of growth; and (4) losses from the banks by diverse causes. Although the structures at which growth suspension occurs are of very different morphologies, and probably are also different in their capacities of temporal displacement, both types of banks are regulated by similar environmental factors and subjected to similar types of constraints. Some important differences between the 2 banks are likely to stem from the lesser longevity of the algal microscopic stages, which would limit the duration of banks of microscopic forms.
\end{abstract}

\section{INTRODUCTION}

In analogy to the seed banks of land plants, Chapman (1986) coined the term 'bank of microscopic forms' for the population of microscopic phases from which macroalgae may develop under adequate environmental conditions. In many algal species, some time elapses between the period of peak spore production and the appearance of juvenile plants detectable in the field. Such lags may be seasonal, and they are often related to climatic conditions. During these periods, the species would survive through microscopic phases of development that act as overwintering stages, under conditions that are stressful for the macroscopic thalli. Hence, the microscopic forms might play an important ecological role which, in land plants, is fulfilled by the seeds that remain dormant in the soil, constituting a 'seed bank'. Besides, some species, mostly fugitive or opportunistic plants, may span generations through persisting in the habitat as seed banks. A similar role might be fulfilled by banks of microscopic forms.

The characteristics and functioning of seed banks have been evaluated in a number of species and different land plant communities (Harper 1977, Grime
1979, Fenner 1985, Leck et al. 1989). In contrast, the analogy between a 'bank of microscopic forms' and a 'seed bank' has not been critically assessed. No attempts have been made at establishing if the microscopic stages actually function as survival banks, either for an algal population or a community; it is unknown if there are interspecific differences in the characteristics of banks of microscopic forms or if such differences are related to the particular successional status of the species; it is unknown whether survival banks are formed solely by microscopic stages or if some macroscopic structures may also have periods of suspended growth; finally, it is unclear whether the ecological functions fulfilled by the bank of microscopic stages are comparable to those of seed banks.

In this study we compare the possible ecological role of a bank of microscopic forms with what is known on the functioning of seed banks. We propose hypotheses on the functioning of banks of microscopic forms by discussing: (1) the origin and morphology of the structures that form either type of bank, (2) the species that may constitute banks, (3) the environmental conditions that allow survival of seeds and microscopic stages in a state of suspended growth, as well as the conditions that trigger the reinitiation of development, and (4) the 
losses from banks that may result by different causes. All these factors have been identified as extremely important in the functional regulation of seed banks (Harper 1977, Grime 1979, Fenner 1985, Leck et al. 1989).

\section{(1) ORIGIN AND MORPHOLOGY}

Seed banks originate from seeds that arrive at the substratum as a 'seed rain', and it is likely that the bank of microscopic forms would originate from a 'spore rain' (see reviews by Hoffmann 1987 and Santelices 1990).

The seeds of terrestrial plants arriving at a habitat are produced partly in the habitat and partly elsewhere. The distances at which the parent plants are located, and the number of plants, would influence the composition and abundance of the propagules arriving at a site (Harper 1977). It appears, though, that most seeds of both wind- and bird-disseminated plants are dispersed over distances of at most 50 m (Smith 1975, Fenner 1985, Murray 1986). A fraction of these seeds does not germinate immediately but is buried in the soil, remaining dormant until environmental conditions become favorable. Thus, seeds may show both spatial and temporal displacements.

Banks of microscopic forms result from the germination of spores arriving at intertidal habitats. These spores probably also originate partly in the habitat and partly in other areas, therefore exhibiting spatial displacement. The distances that algal spores may travel away from parent plants are generally short, usually not exceeding a few meters (Anderson \& North 1966, Dayton 1973, 1985, Paine 1979, Sousa 1984, Vandermeulen \& DeWreede 1986, Hoffmann \& Camus 1989; also see reviews by Hoffmann 1987 and Santelices 1990). From this perspective, the capacity for spatial displacement of seaweed spores does not seem to greatly differ from that of seeds. On the other hand, spores would lack dormancy periods; hence their capacity for temporal displacement would be rather limited. This role would be fulfilled by microscopic forms that remain in a state of suspended growth.

Because seed bank studies rarely consider dispersal syndromes (Pickett \& McDonnell 1989) it is difficult to relate the ability to enter a bank of buried seeds to their morphology. Nevertheless, in some species, the shape of seeds may favor lodging in soil crevices (Silvertown 1982). On the other hand, the size of seeds seems to be important; e.g. seeds that form seed banks are often small-sized. Usually, large seeds do not remain dormant in the soil, since they are liable to be destroyed by fungi, bacteria or rodents. Predation pressure on large seeds, especially those with thin testa, is generally much higher than that on small or tough seeds (Janzen 1969, 1971, O'Dowd \& Gill 1984, Foster 1986, Louda 1989, Schupp et al. 1989). However small seeds of some species are intensively predated by ants (Brown et al. 1979, Mills \& Kummerow 1989).

Although significant differences in spore size have been described for different seaweed taxa, their range of dimensions is much narrower that of land plant seeds: spore size, at least in red algae, ranges from 15 to $120 \mu \mathrm{m}$ (Ngan \& Price 1979), whereas seed size varies from about $0.1 \mathrm{~mm}$ in diameter (in Orchidaceae) to around $12 \mathrm{~cm}$ (in Mora dimorphandra) (Van der Pijl 1982). Further, no relation has been established so far between spore size or morphology and the capacity to form banks of microscopic stages. Rather, this capacity would be related to the type of life cycle of the species, which is apparently independent from spore size. Gametophytes are the stages most frequently mentioned as able to survive in a state of suspended growth (Table 1). These gametophytes are mainly of the creeping, filamentous type. However, experimental data are lacking to interpret the survival value of the different morphologic types of microscopic stages.

In many forest trees, seeds do not enter seed banks and germinate soon after seed-drop, although the timing of germination varies in different communities (Beatley 1974, Harper 1977, Garwood 1983). Under the canopy of mature trees, seedlings of some species develop that persist with almost no further growth; some survive for long periods and are able to rapidly increase growth when gaps occur in the canopy (Silvertown 1982). Such seedlings constitute a 'seedling bank', that functions in the same way as seed banks (Grime 1979). Seedling banks are frequent for woody species. In many large-seeded species that suffer high seed-losses from predation, persistent seedlings may be a preferred alternative to seed banks, although seedling banks must tolerate the understorey environment (Parker et al. 1989). An analogous response seems to have evolved in some macroalgae. In several species, in which unfavorable environmental conditions cause a suspension of growth of the early phases of macroscopic development, populations of juvenile sporelings develop that survive with little growth for periods of time. Some individuals of these populations resume growth when conditions improve. Kirkmann (1982) found that small sporophytes of Ecklonia radiata, that survive in shaded areas, were able to develop and grow rapidly after artificial clearings in the E. radiata canopy. Similar findings have been reported for populations of Macrocystis pyrifera from various latitudes (Dayton et al. 1984, Santelices \& Ojeda 1984).

Summarizing, whereas the dispersal units of plants and seaweeds seem to show no marked differences in 


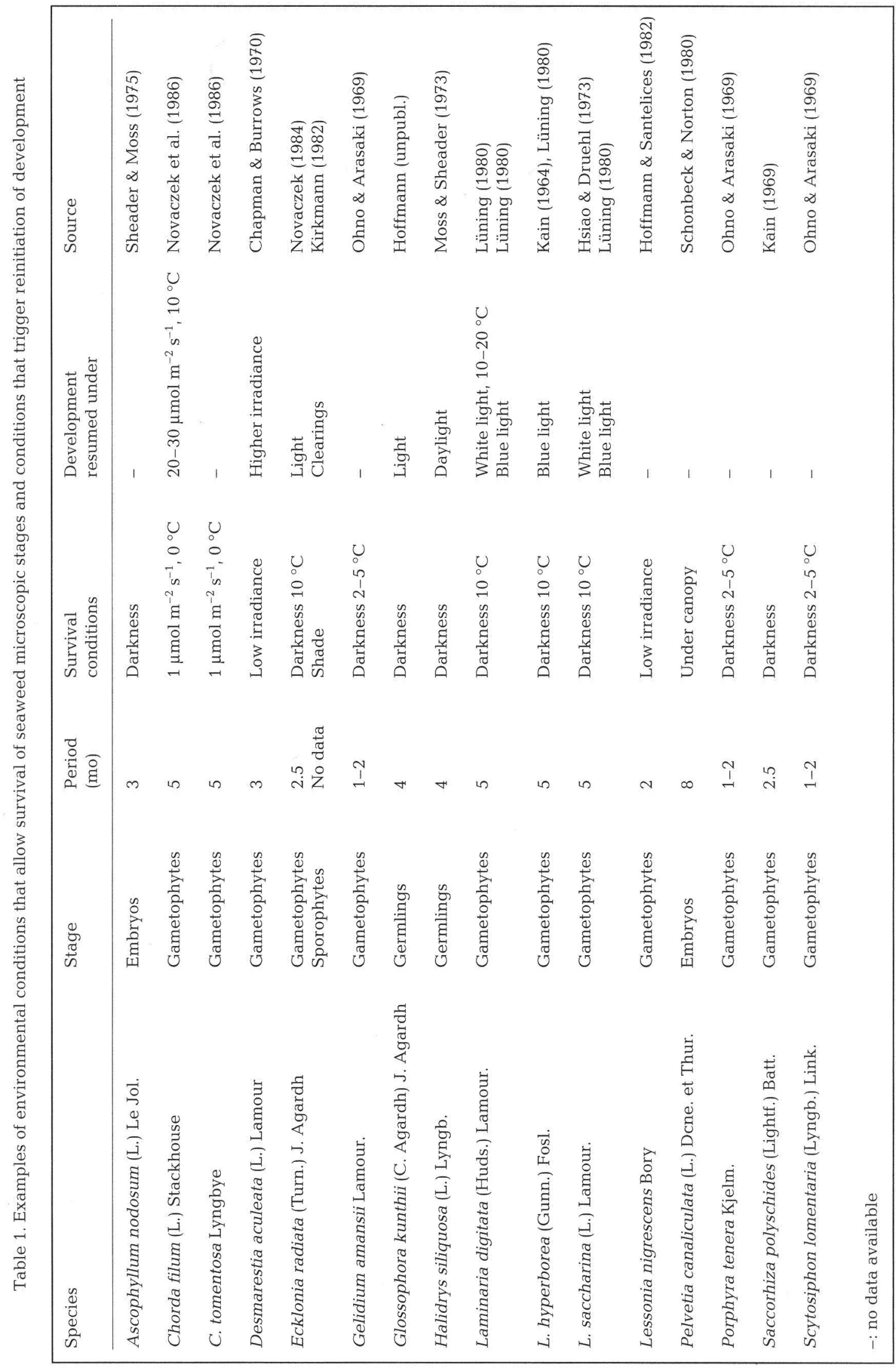


their dispersibility, their patterns of temporal displacement and the stages at which growth can be suspended are conspicuously different. In plants, growth suspension affects primarily seeds, and, in some species, the seedling stage. In seaweeds, periods of growth suspension occur in a wider variety of microscopic structures, corresponding to different phases of the life cycle (mainly gametophytes, but also embryos, germlings, or newly formed sporophytes). Growth suspension may also affect sporelings, i.e. small-sized macroscopic plants that resemble the seedlings of land plants.

\section{(2) COMPOSITION}

Changes in seasonal fertility, in the numbers of progagules arriving at the habitat, and differences in propagule longevity are likely to affect the composition of seed banks and banks of microscopic forms.

\section{Seasonal fertility fluctuations}

Seasonality in seed production and differences in seed germination capacity produce temporal variations in the composition of seed banks. Some of the seeds produced in the current season germinate immediately, others are lost due to different causes, and only a fraction becomes incorporated into the seed bank (Grime 1979).

There is evidence that benthic algal spores are usually present in seawater, since large numbers of opportunistic algal spores arrive continuously at the intertidal zone (Hruby \& Norton 1979, Hoffmann \& Ugarte 1985, Zechmann \& Mathieson 1985). However the specific composition of spores may change due to the seasonality in spore production that characterizes seaweeds in most climatic regions (Hoffmann 1987, Santelices 1990). It is also likely that, as in land plants, where only a small part of the seeds that arrive as seed rain is buried to form the seed bank, only a small fraction of the seaweed propagules enters the bank of microscopic stages.

Since microscopic stages last only for a few months (see below), those constituting a bank of microscopic forms would be replaced more or less continuously. However, in some seasons there might be competition for space among microscopic stages of different species. As reported for seed banks of several species, the probability of seed germination significantly decreases with an increase in seed density (Bergelson \& Perry 1989). In kelps, density-dependent mortality of the microscopic stages has been shown for Macrocystis pyrifera and Pterygophora californica. For both kelps, a minimum density of at least 1 spore $\mathrm{mm}^{-2}$ was necessary to allow for fertilization, which would result in density-mortality of early recruits (Reed 1990). Due to this requirement of high density in spore settlement, competition for space might be even greater in banks of microscopic stages than in seed banks.

\section{Numbers of propagules}

Large numbers of seeds may be found in seed banks of a wide range of communities. Estimates vary between $10^{-2}$ and $10^{-5} \mathrm{~m}^{-2}$ (Fenner 1985), according to the specific adaptive strategy; ruderal species usually contribute large numbers of propagules, whereas the numbers of seeds of late successional species are usually smaller (Grime 1979).

There is scarce knowledge on the numbers of seaweed microscopic forms in intertidal habitats. The existence of large numbers was suggested when numerous sporelings of several species developed on apparently bare stones collected in the intertidal zone and cultured in enriched seawater (Burrows 1958, Neushul \& Dahl 1967, Chapman \& Burrows 1970). Chapman (1984), by using ceramic pieces placed under a kelp forest, estimated that spores settling in the microbenthos developed each year into nearly $6 \times 10^{-6}$ microscopic stages $\mathrm{m}^{-2}$. These results suggest that, as in seed banks, there are large numbers of microscopic stages in banks of microscopic forms. A relationship may exist between numbers and algal life strategy, because of the differences in propagule production that characterize many opportunistic and late successional algae (Boney 1960, Amsler \& Searles 1980, Hoffmann \& Ugarte 1985).

\section{Propagule longevity}

The survival times of terrestrial plant seeds are highly variable. Longevity has been related to seed size, among other attributes. Thus, while the small seeds of many herbaceous plants may survive for around $50 \mathrm{yr}$ or more, large seeds (mainly of trees) usually do not survive for over $5 \mathrm{yr}$ (Harper 1977). It has been proposed that seed longevity influences the functioning of seed banks; the greater it is, the more rapidly a dormant seed bank will accumulate (Parker et al. 1989). Two extreme seed bank types have been determined (Grime 1979). In one type, defined as 'persistent', some of the component seeds are at least $1 \mathrm{yr}$ old, while in the 'transient' seed bank, some seeds germinate shortly after release, and none remain in the habitat in a viable condition for over $1 \mathrm{yr}$ (Parker et al. 
1989). Between these 2 groups, intermediate types may occur. It could be assumed that fluctuations in composition are due rather to changes in the transient fraction than to changes in the persistent fraction of a seed bank.

Data available on the longevity of algal microscopic stages (Table 1) show that, in culture, microscopic stages of several species survive from 3 to $8 \mathrm{mo}$. The maximum survival period reported in field conditions is that of Pelvetia canaliculata. Embryos of this species have been found in the field up to $8 \mathrm{mo}$ after the end of the fertile season (Schonbeck \& Norton 1980). However, how the longevity of the microscopic stages influences the functioning of a bank of microscopic forms has not yet been evaluated.

Microscopic stages of seaweed species may resume their development when returned to adequate conditions. In 8 of the 14 references listed in Table 1 it was reported that the microscopic stages resumed growth when conditions were improved. The longevity of microscopic stages might be related to seaweed life strategy, but scarce information on this point was found, since, as shown in Table 1, most data refer to long-lived species.

The longevity of propagules relative to the longevity of parent plants is potentially important since it influences the chance of any given propagule to replace its parent. The situation is very different in annual land plants, that usually live for less than 1 yr but whose seed banks persist over many years, and in perennials that live for many years but frequently do not have persistent seed banks.

Little is known on the survival of algal microscopic stages. The gametophytes of some kelp species may remain dormant for months (Lüning 1980), but the majority of Macrocystis and Pterygophora gametophytes in Southern California appear to live at most for only a few weeks (Deysher \& Dean 1986). A probable outcome of this shorter duration would be that no really persistent banks of microscopic stages would exist for seaweeds; therefore, fluctuations in the composition of banks would be more marked in marine than in terrestrial habitats.

Persistent seed banks are characteristic of species of early successional phases, whose seeds lie dormant, and germinate only after some disturbance has occurred (Harper 1977, Grime 1979). In contrast, communities sujected to little disturbance, for example some types of forests, have few buried viable seeds (Fenner 1985). As a result, in habitats that are frequently disturbed, the species composition of the seed bank is usually similar to that of the vegetation, while in habitats with mature vegetation the disparity between the seed bank and the vegetation increases; in some cases, no species common to both are found
(Silvertown 1982, Fenner 1985). Although no such studies have been undertaken for marine habitats, we hypothesize that this type of situation would not occur because of the absence of a really persistent bank of microscopic stages.

In brief, the comparative analysis of the composition of seed banks and banks of microscopic forms indicates somewhat similar patterns in seasonal fertility and in the fluctuations in numbers of propagules. However, the lesser longevity of microscopic stages, in comparison to seeds, probably determines some important differences. Since the longevity of different types of microscopic stages seems to be similar, it is likely that a distinction between persistent and transient banks may not to established for seaweeds.

In stable environments, seeds accumulate with time, and the compostion of seed banks becomes increasingly dissimilar to that of the aboveground vegetation. Thus, seed banks would represent records of past and present vegetation of the area (Harper 1977). Since some seeds may remain viable for long periods, when due to some circumstance they germinate simultaneously, genetic exchange may occur between plants of different generations. Due to the limited survival capacity of microscopic stages, this is less likely to occur in seaweeds. Also, while 'fugitive' species can persist in the seed bank between disturbances in some terrestrial plant communities, this will probably not occur in algal communities.

\section{(3) ENVIRONMENTAL CONDITIONS}

The environmental conditions that allow the survival of seeds during unfavorable seasons are widely documented, as are the factors that trigger seed germination. As for terrestrial plants, several authors report on seaweed species in which certain environmental factors, inadequate for normal development, allow survival of the microscopic stages in a state of suspended growth. However, in most reports, the data on the survival capacity of microscopic stages arose in experiments aimed at studying other problems, and its ecological meaning has been little emphasized. For example, Kain (1964) reported that, in Britain, sporophytes of Laminaria hyperborea are reproductive only between October and the beginning of April, suggesting that gametophytes must become established and survive during the winter; however the existence of a bank of microscopic forms was not considered until much later.

In seed banks, germination is inhibited by a number of factors. The seeds of many species forming persistent seed banks do not germinate in darkness, and low or high temperature, moisture content, or 
decreased oxygen levels in the soil may inhibit germination (Grime 1979, Baskin \& Baskin 1989). In turn, what is known of the regulation of seaweed microscopic stages under experimental conditions should help to predict how a bank of microscopic stages is regulated in the field.

Under experimental conditions, spores of several seaweed species can germinate in complete darkness, giving rise to microscopic forms. In several algal groups these microscopic forms are able to survive, in a state of suspended growth, under conditions of very low illuminance, or even darkness, for periods of 2 to 7 mo (Table 1). For example, Lüning (1980) found that, in the sea, gametophytes of 3 Laminaria species survive the dark winter months with very little vegetative growth of the primary cell. The finding of Lüning (1981), who established saturation irradiances of 4 to 5 $\mu \mathrm{mol} 1 \mathrm{~m}^{-2} \mathrm{~s}^{-1}$ for growth of germlings of deep-water red algae, suggests that these microscopic stages are adapted to survive with very low illuminances. In some cases, the effect of darkness is associated with low temperature (Table 1).

In other species, the limiting conditions for survival may be excessive light, or too high temperatures during summer, however little conclusive evidence has been found so far. For instance, differential resistance to summer conditions may explain the seasonal behavior of Chorda filum and C. tomentosa (Table 1). Both species grow in Nova Scotia, (Canada), but while sporophytes of $C$. filum appear in the field in spring, survive the summer, and do not persist in winter, those of $C$. tomentosa appear in late winter but do not tolerate the summer conditions. These differences have been explained in terms of different temperature requirements of the gametophytes for sexual reproduction, and of temperature tolerance of the sporophytes: $C$. filum gametophytes reproduced from 5 to $12{ }^{\circ} \mathrm{C}$, but rarely did at 0 and $15^{\circ} \mathrm{C}$. In culture, sporophytes survived between 0 and $24{ }^{\circ} \mathrm{C}$. On the other hand, C. tomentosa gametophytes reproduced at $5{ }^{\circ} \mathrm{C}$ and occasionally at $10{ }^{\circ} \mathrm{C}$ but not at higher temperatures. In culture, sporophytes tolerated from -1 to $15^{\circ} \mathrm{C}$ (Novaczek et al. 1986).

Reports of species with microscopic forms able to survive periods of adverse environmental conditions refer mostly to algae of temperate regions; however, there is some evidence suggesting that banks of microscopic forms also develop in tropical latitudes or in coral reefs. Hay \& Norris (1984) found that, in several species of Gracilaria in the Caribbean Sea, there is a period of 4 to 5 mo between the reproductive peak in December/January and the appearance of juvenile plants. Most likely, some early stages of development of these species would persist in a state of slow or suspended growth during the unfavorable period.
Summarizing, the main abiotic factors causing growth suspension on microscopic stages seem to be light (mainly insufficient illuminance or complete darkness), and inappropriate temperature (mainly too low).

On the other hand, seeds that survived unfavorable periods resume their development once environmental conditions improve. Adaptation to seasonal phenomena requires that the behavior of the propagules be synchronized with seasonal changes. Light and temperature are important environmental signals for plants. For some species, daylength is a reliable indicator, and the process has been called 'seasonal dormancy' (Harper 1977). In contrast, in places where the occurrence of favorable conditions is unpredictable (for instance rain in desert regions), daylength is not a useful indicator, and dormancy tends to be released by the direct experience of the favorable condition. This is called 'opportunistic dormancy'. For instance, in persistent seed banks, the onset of germination may occur when buried seeds are unearthed and exposed to light. In other species, germination of buried seeds is brought about by increased soil temperature and or moisture (Thompson \& Grime 1979, Garwood 1983).

In seaweeds, increases in irradiance, resulting from seasonal changes of illuminance or clearings in the canopy, and increases in temperature are the factors most frequently mentioned as triggering the reinitiation of development in microscopic stages, as shown in Table 1 (Lüning \& Neushul 1978, Lüning 1980, Deysher \& Dean 1986). In Macrocystis pyrifera, successful recruitment of sporophytes from outplanted gametophytes would occur only during periods of suitable temperature and irradiance, i.e. 'recruitment windows' (Deysher \& Dean 1986, Reed et al. 1988). In a few cases, besides an increase in quantum dose, wavelength or photoperiod (Kain 1964, Lüning 1980) may be involved (Table 1). However, little is known on the role these factors may play in regulating the seasonal activity of a bank of microscopic stages. It could be assumed that, in algae whose macroscopic phase has definite requirements that occur seasonally, the microscopic phase might also be regulated by daylength.

Thus, the above findings suggest that the reinitiation of development in banks of microscopic stages might be triggered by environmental signals similar to those stimulating the onset of seed germination.

\section{(4) LOSSES}

There is evidence suggesting that, in land plants, large numbers of seeds are lost from seed banks due to several causes. Losses may result from germination, from processes leading to deep burial or redispersal, 
from the action of pathogens or animals (predation), and from natural senescence and death (Harper 1977, Leck et al. 1989). We hypothesize that a parallel situation would occur in seaweeds, in that a significant proportion of a bank of microscopic forms is probably lost due to several reasons, the main causes being different pathogenic agents, predation, sand burial, or persistence of inadequate conditions for development that result in death of the microscopic forms.

Bacteria or fungi probably destroy many microscopic stages, though no evaluation of these causes has been documented in seaweeds.

Predation has one of the most obvious and direct impacts on the survival of seeds in the soil (Louda 1989, Schupp 1990), thus influencing the composition of seed banks in a manner opposite to seed longevity. Each year a substantial portion of the potential recruitment to plant populations is lost to seed predators; mortality on the ground after seedfall is often in excess of $75 \%$ (Schupp 1988a, b). The evidence suggests that seed predators select seeds differentially, determining the average value of key characteristics of seeds that remain in the soil. By finding and using clumped and larger seeds, predators will reinforce other pressures that select for seed traits characteristic of persistent seed banks, including small seed size and hard seed coats (Louda 1989). Seed predation is greatest beneath the parent crown and decreases with distance (Howe \& Smallwood 1982, Schupp 1988a, b).

A significant proportion of microscopic stages may also be consumed by a diversity of invertebrates, so that the functioning of the bank of microscopic forms may be masked by predation. In one of the first studies that mentioned the ecological effects of grazers on microscopic stages, Jones (1946) postulated that herbivores can strongly affect the first phases of seaweed development. Herbivores may graze on just-settled spores, on microscopic stages, or on microscopic juveniles. It has been suggested (Dayton 1985, Reed et al. 1988) that since zoospores of brown algae lack a cell wall, kelp gametophytes are most vulnerable to predation soon after spore germination, before a protective wall is formed. The main organisms probably consuming gametophytes are protozoans and meiofauna, filter feeders such as bivalves and tunicates, and detritus feeders such as small crustaceans, polychaetes, gastropods, chitons, and some asteroids (Dayton 1985). However, there has been little evaluation of this point. Because of the methodological difficulties involved, studies on the effect of grazers on algal recruitment in the field have mostly centered on juvenile plants once they become visible to the unaided eye, and few attempts have been made to study these effects at the microscopic stages. Vadas et al. (1982) evaluated grazing pressure by settling ferti- lized eggs of Ascophyllum nodosum (L.) Le Jolis on clay pottery shards and on natural surfaces that were then placed in the sea. They found that, under normal grazing pressure, nearly $100 \%$ of the zygotes were killed within $2 \mathrm{mo}$; but if grazers were excluded, survivorship improved. Breen \& Mann (1976), and Chapman (1981) found that some species of echinoids would be able to feed on microscopic stages of diverse algal species. Survival to grazing pressure probably depends on the relative densities of microscopic forms and of grazers.

Whereas burial of seeds is one aspect of seed banks which may be important for the long-term survival of some species (Garwood 1989, Leck 1989), burial by sand and sediments, as well as abrasion, are probably sources of mortality for the microscopic forms of many species. However there is little information available on this point. Small amounts of sediment reduce survival of Macrocystis pyrifera gametophytes (Devinny \& Volse 1978, Dayton 1985, Deysher \& Dean 1986); in contrast, the gametophytes of other kelp species such as Laminaria farlowii and Eisenia arborea are more resistant to sedimentation and scouring (Dayton 1985).

Inadequate conditions for development may be of 2 types. First, an excessive duration of the environmental conditions that maintain suspended growth may kill part of the bank of microscopic stages. In culture, microscopic stages of most species probably do not survive periods of over 5 mo under unfavorable conditions (Table 1). There is evidence suggesting that the survival of microscopic stages is not significantly longer in the field. Laminaria saccharina sporophytes suffered close to $100 \%$ mortality in the sporeling stage when recruited in winter (Parke 1948). Prolonged shading of microscopic stages by adult plants may also cause mortality. For instance, it has been estimated that, from nearly $6 \times 10^{6} \mathrm{~m}^{-2}$ microscopic Laminaria gametophytes that develop on the substratum each year, only about $3 \mathrm{~m}^{-2}$ visible plants develop. This could result from shading by the cover of red algal turf species (Chapman 1984). Similarly, the existing canopy severely limits recruitment of microscopic plants of Egregia laevigata into the macroscopic phase (Black 1974), and the whiplash action of blades of the dominant intertidal algae of exposed coasts may prevent development into macroscopic plants (Dayton 1975, Santelices \& Ojeda 1984).

A second type of inadequate environmental conditions occurs when propagules settle at intertidal heights other than their normal distribution ranges. For instance, microscopic stages from subtidal species may not withstand the light conditions prevailing at higher levels, or the high temperatures and periodic desiccation occurring at low tides. Thus, Lüning (1980) reported that gametophytes of 3 species of Laminaria 

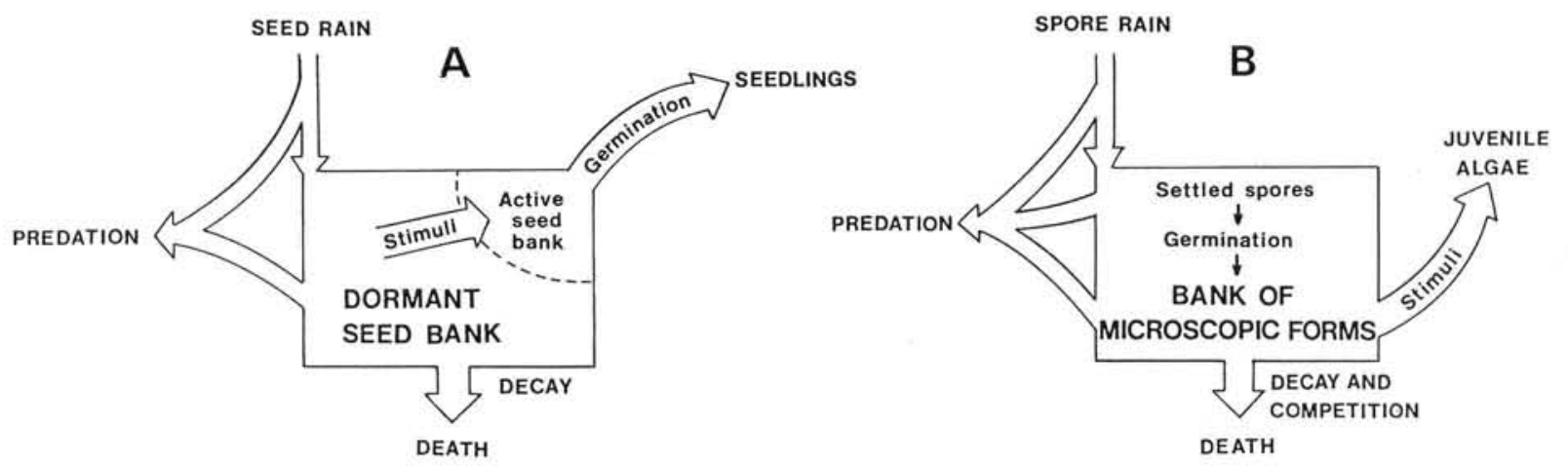

Fig. 1. Comparisons of (A) the dynamics of populations of seeds in the soil (after Harper 1977), and (B) proposition for the dynamics of populations of microscopic forms in marine habitats

were killed within minutes when exposed to sunlight, and at about $20^{\circ} \mathrm{C}$ the same species exhibited sudden decreases in growth rates. It may be predicted that such limitations in tolerance probably contribute to inducing differences between the specific composition of the spores arriving at the higher intertidal and the microscopic stages that actually develop.

\section{CONCLUSIONS AND SUGGESTIONS FOR FUTURE RESEARCH}

There is still little knowledge on the functioning of banks of microscopic stages. However, based on what is known of the microscopic stages in the life history of seaweeds, we identified some of the factors that probably regulate the bank of microscopic forms, and propose hypotheses on its functioning. We postulate that the dynamics of a bank of microscopic forms and those of a seed bank are analogous in several ways, as depicted in Fig. 1. The seed bank of land plants (Fig. 1A) originates from a seed rain. Seeds that are not lost by diverse causes (predation, decay) remain in the soil until environmental stimuli trigger germination. A bank of microscopic forms (Fig. 1B) probably originates from a spore rain, microscopic stages resulting from germination of settled spores. Banks of microscopic stages and seed banks seem to be subjected to similar constraints, such as predation or losses through bacterial or fungal attack. These constraints may produce the loss of a great proportion of seeds and probably also of microscopic stages. Losses through competition for space are probably important in banks of microscopic forms. On the other hand, the total number of species present in either bank may exceed, at any given time, that in the macroscopic vegetation.

The duration of both types of banks would be different, the microscopic stages of most species probably not surviving over 5 to 6 mo, whereas seeds in seed banks may survive for many years. These different time scales may have important consequences on the habitat dynamics. As in seed banks, it may be expected that the relative importance of banks of microscopic forms could vary among different algal communities. Differences in spore production, dispersal, predation and survival of microscopic stages may also account for many characteristics of banks of microscopic forms. Terrestrial seed banks contain dormant seeds that may have been deposited by different generations of plants, perhaps over several decades; therefore, when, under some circumstances, seeds are brought to the surface, representatives of different generations may germinate simultaneously. A bank of microscopic stages may also contain representatives of more than one generation but, since the duration of microscopic stages is much shorter than that of seeds, it is likely that only a small number of generations will coexist. On the other hand, seeds of opportunistic plant species usually have long-lived seeds that form persistent seed banks, whereas those of more perennial, late successional species usually do not form persistent banks. The scarce knowledge on the behavior of algal microscopic stages does not yet allow the establishment of any relationship between the duration of banks and their survival value.

In conclusion, we feel that the following are among the main points that should be addressed in future research:

- The role of the bank of microscopic forms in the regeneration of a community has to be distinguished from regeneration through spores that have dispersed recently into a site.

- Although many problems of the physiological regulation of microscopic forms have to be studied in the laboratory (for instance their longevity under various environmental conditions), their relevance in regulating the dynamics of banks of micoscopic forms must 
be compared with the results of field experiments conducted in different habitats and communities.

- The relative susceptibility of microscopic stages to predator impact is largely unknown. Testable predictions would be valuable for the types of microscopic forms that are likely to have their dynamics influenced by predators. For land plants, at least, it has been proposed that fugitive species are highly vulnerable to seed predator impact in the determination of their abundance and distribution.

- The relative importance of banks of microscopic forms in the dynamics of fugitive and late successional algal species should be evaluated.

Acknowledgements. We acknowledge financial support by FONDECYT, grant 801/90.

\section{LITERATURE CITED}

Amsler, C. D., Searles, R. B. (1980). Vertical distribution of seaweed spores in a water column offshore of North Carolina. J. Phycol. 16: 617-619

Anderson, E. K., North, W. J. (1966). In situ studies of spore production and dispersal in the giant kelp Macrocystis. Proc. Int. Seaweed Symp. 5: 73-86

Bergelson, J. R., Perry, R. (1989). Interspecific competition between seeds: relative planting date and density affect seedling emergence. Ecology 70: 1639-1644

Baskin, J. M., Baskin, C. C. (1989). Physiology of dormancy and germination in relation to seed bank ecology. In: Leck, M. A., Parker, V. T., Simpson, R. L. (eds.) Ecology of soil seed banks. Academic Press, San Diego, p. 53-65

Beatly, J. C. (1974). Phenological events and their environmental triggers in Mojave desert ecosystems. Ecology 55: 856-863

Black, R. (1974). Some biological interactions affecting intertidal populations of the kelp Egregia laevigata. Mar Biol. 28: $189-198$

Boney, A. D. (1960). Observations on the spore output of some common red algae. Br. phycol. Bull. 2: 36-37

Breen, P. A., Mann, K. H. (1976). Changing lobster abundance and the destruction of kelp beds by sea urchins. Mar. Biol. 34: $137-142$

Brown, J. H., Davidson, D. W., Reichman, O. J. (1979). An experimental study of competition between seed-eating desert rodents and ants. Am. Zool. 19: 1129-1143

Burrows, E. M. (1958). Subtidal algal population in Port Erin Bay, Isle of Man J. mar. biol. Ass. U.K. 37: 687-703

Chapman, A. R. O. (1981). Stability of sea urchin dominated barren grounds following destructive grazing of kelp in St. Margaret's Bay, eastern Canada. Mar. Biol. 62: 307-311

Chapman, A. R. O. (1984). Reproduction, recruitment and mortality in two species of Laminaria in south-west NovaScotia. J. exp. mar. Biol. Ecol. 78: 99-109

Chapman, A. R. O. (1986). Population and community ecology of seaweeds. In: Blaxter J. H. S., Southwood, A. J. (eds) Advances in marine biology. Academic Press, London, 23: $1-161$

Chapman, A. R. O., Burrows, E. M. (1970). Experimental investigations into the controlling effects of light conditions on the development and growth of Desmarestia aculeata (L.) Lamour. Phycologia 9: 103-108

Dayton, P. K. (1973). Dispersion, dispersal and persistence of the annual intertidal alga Postelsia palmaeformis. Ruprecht. Ecology 54: 433-438

Dayton, P. K. (1975). Experimental evaluation of ecological dominance in a rocky intertidal algal community. Ecol. Monogr. 45: 137-159

Dayton, P. K., Currie, V., Gerrodette, T., Keller, B. D., Rosenthal, R., Ventresca, D. (1984). Patch dynamics and stability of some California kelp communities. Ecol. Monogr. 54: 253-289

Dayton, P. K. (1985). Ecology of kelp communities. Ann. Rev. Ecol. Syst. 16: 215-245

Deysher, L. E., Dean, T. A. (1986). Critical irradiance levels and the interactive effects of quantum irradiance and dose on gametogenesis in the giant kelp, Macrocystis pyrifera. J. Phycol. 20: 520-524

Devinny, J. S., Volse, L. A. (1978). The effects of sediments on the development of Macrocystis pyrifera gametophytes. Mar. Biol. 48: 343-348

Fenner, M. (1985). Seed ecology. Chapman and Hall Ltd, London

Foster, S. A. (1986). On the adaptive value of large seeds for tropical moist forest trees: a review and synthesis. Bot. Rev. 52: 260-299

Garwood, N. C. (1983). Seed germination in a seasonal tropical forest in Panama: a community study. Ecol. Monogr. 53: 159-181

Garwood (1989). Tropical soil seed banks: a review. In: Leck, M. A., Parker, V. T., Simpson, R. L. (eds.) Ecology of soil seed banks. Academic Press, San Diego, p. 149-209

Grime, J. P. (1979). Plant strategies and vegetation processes. John Wiley and Sons, Chichester

Harper, J. L. (1977). Population biology of plants. Academic Press, London

Hay, M. E., Norris, J. N. (1984). Seasonal reproduction and abundance of six sympatric species of Gracilaria Grev. (Gracilariaceae; Rhodophyta) on a Caribbean subtidal sand plain. Hydrobiologia 116/117: 63-94

Hoffmann, A. J. (1987). The arrival of seaweed propagules at the shore: a review. Botanica mar. 30: 151-166

Hoffmann, A. J., Santelices, B. (1982). Effects of light intensity and nutrients on gametogenesis of Lessonia nigrescens Bory (Phaeophyta). J. exp. mar. Biol. Ecol. 78: 177-186

Hoffmann, A. J., Ugarte, R. (1985). The arrival of propagules of marine macroalgae in the intertidal zone. J. exp. mar. Biol. Ecol. 92: 83-95

Hoffmann, A. J., Camus, P. (1989). Sinking rates and viability of spores from benthic algae of central Chile. J. exp. mar. Biol. Ecol. 126: 281-291

Howe, H. F., Smallwood, J. (1982). Ecology of seed dispersal. Ann. Rev. Ecol. Syst. 13: 201-228

Hruby, T., Norton, T. A. (1979). Algal colonization on rocky shores in the Firth of Clyde. J. Ecol. 67: 65-77

Hsiao, S. I. C., Druehl, L. D. (1973). Environmental control of gametogenesis in Laminaria saccharina. IV. In situ development of gametophytes and young sporophytes. J. Phycol. 9: 160-164

Janzen, D. H. (1969). Seed eaters versus seed size, number, toxicity and dispersal. Evolution 23: 1-27

Janzen, D. H. (1971). Seed predation by animals. Ann. Rev. Ecol. Syst. 2: 465-492

Jones, N. S. (1946). Browsing of Patella. Nature, Lond. 158: 557

Kain, J. M. (Mrs N. S. Jones) (1964). Aspects of the biology of Laminaria hyperborea. III Survival and growth of gametophytes. J. mar. biol. Ass. U.K. 44: 415-433 
Kain, J. M. (Mrs N. S. Jones) (1969). The biology of Laminaria hyperborea. V. Comparison with early stages of competitors. J. mar. biol. Ass. U.K. 49: 455-473

Kirkmann, H. (1982). The first year in the life history and the survival of the juvenile marine macrophyte, Ecklonia radiata (Turn.) J. Agardh. J. exp. mar. Biol. Ecol. 55: 243-254

Leck, M. A. (1989). Wetland seed banks. In: Leck, M. A., Parker, V. T., Simpson, R. L. (eds.) Ecology of soil seed banks. Academic Press, San Diego, p. 283-305

Leck, M. A., Parker, V. T., Simpson, R. L. (1989). Ecology of soil seed banks. Academic Press, San Diego

Louda, S. M. (1989). Seed bank processes. In: Leck, M. A., Parker, V. T., Simpson, R. L. (eds.) Ecology of soil seed banks. Academic Press, San Diego, p. 25-51

Lüning, K. (1980). Critical levels of light and temperature regulating the gametogenesis of three Laminaria species (Phaeophyceae). J. Phycol. 16: 1-15

Lüning, K. (1981). Light. In: Lobban, C. S., Wynne, M. (eds.) The biology of seaweeds. Bot. Monogr. 17: 326-354

Lüning, K., Neushul, M. (1978). Light and temperature demands for growth and reproduction of laminarian gametophytes in central and southern California. Mar. Biol. 45: 297-309

Mills, J. N., Kummerow, J. (1989). Herbivores, seed predators, and chaparral succession. In: Keely, S. C. (ed.) The California chaparral. Paradigms revisited. Science Series Nat. Hist. Museum 34, Los Angeles County, p. 49-56

Moss, B., Sheader, A. (1973). The effect of light and temperature upon the germination and growth of Halidrys siliquosa (L.) Lyngb. (Phaeophyceae, Fucales). Phycologia 12: $63-68$

Murray, K. G. (1986). Consequences of seed dispersal for gap dependent plants: relationships between seed shadows, germination requirements, and forest dynamic processes. In: Estrada, A., Fleming, T. H. (eds.) Junk, Dordrecht, p. 187-198

Neushul, M., Dahl, A. L. (1967). Composition and growth of subtidal parvisilvosa from Californian kelp forests. Helgoländer wiss. Meeresunters. 15: 480-488

Ngan, Y., Price, I. R. (1979). Systematic significance of spore size in the Florideophyceae (Rhodophyta). Br. Phycol. J. 14: $285-303$

Novaczek, I. (1984). Response of Ecklonia radiata (Laminariales) to light at $15^{\circ} \mathrm{C}$ with reference to the field light budget at Goat Island Bay, New Zealand. Mar. Biol. 80: 263-272

Novaczek, I., Bird, C. J., McLachlan, J. (1986). The effect of temperature on development and reproduction in Chorda filum and C. tomentosa (Phaeophyta, Laminariales) from Nova Scoia. Can. J. Bot. 64: 2414-2420

O'Dowd, D. J., Gill, A. M. (1984). Predator satiation and site alternation following fire: mass reproduction of alpine ash (Eucalyptus delegatensis) in southeastern Australia. Ecology 65: 1052-1066

Ohno, M., Arasaki, S. (1969). Examination of the dark treatment at spore stage of seaweeds. (fide Lüning 1980). Bull. Jap. Soc. Phycol. 17: 37-42

Parke, M. (1948). Studies in the British Laminariaceae: I. Growth in Laminaria saccharina (L.) Lamour. J. mar. biol. Ass. U.K. 17: 652-709

Parker, V. T., Simpson, R. L., Leck, M. A. (1989). Pattern and process in the dynamics of seed banks. In: Leck, M. A.,
Parker, V. T., Simpson, R. L. (eds.) Ecology of soil seed banks. Academic Press, San Diego, p. 367-383

Paine, R. T. (1979). Disaster, catastrophe and local persistence on the sea palm, Postelsia palmaeformis. Science 205: 685-687

Pickett, S. T. A., McDonnell, M. J. (1989). Seed bank dynamics in temperate deciduous forest. In: Leck, M. A., Parker, V. T., Simpson, R. L. (eds.) Ecology of soil seed banks. Academic Press, San Diego, p. 123-147

Reed, D. C. (1990). The effects of variable settlement and early competition on patterns of kelp recruitment. Ecology 71: $776-787$

Reed, D. C., Laur, D. L., Ebeling, A. W. (1988). Variation in algal dispersal and recruitment: the importance of episodic events. Ecol. Monogr. 58: 321-335

Santelices, B. (1990). Patterns of reproduction, dispersal and recruitment in the seaweed. In: Barnes, M. (ed.) Oceanogr. mar. Biol. A. Rev. 28: 177-276

Santelices, B., Ojeda, P. (1984). Effects of canopy removal on the understory algal community structure of coastal forests of Macrocystis pyrifera from southern South America. Mar. Ecol. Prog. Ser. 14: 165-173

Schonbeck, M. V., Norton, T. A. (1980). Factors controlling the lower limits of fucoid algae on the shore. J. exp. mar. Biol. Ecol. 43: 131-150

Schupp, E. W. (1988a). Factors affecting post-dispersal seed survival in a tropical forest. Oecologia (Berl.) 76: 525-530

Schupp, E. W. (1988b). Seed and early seedling predation in the forest undestory and in treefall gaps. Oikos 51: 71-78

Schupp, E. W. (1990). Annual variation in seedfall, postdispersal predation, and recruitment of a neotropical tree. Ecology 71: 504-515

Schupp, E. W., Howe, H. F., Augspurger, C. K., Lavey, D. J. (1989). Arrival and survival in tropical treefall gaps. Ecology 70: 562-564

Sheader, A., Moss, B. (1975). Effect of light and temperature on germination and growth of Ascophyllum nodosum (L.) Le Jol. Estuar. coast. mar. Sci. 3: 125-132

Silvertown, J. W. (1982). Introduction to plant population ecology. William Clowes Ltd, London

Smith, A. J. (1975). Invasion and ecesis of bird-disseminated woody plants in a temperate forest sere. Ecology 56: 19-34

Sousa, W. P. (1984). Intertidal mosaics: patch size, propagule availability, and spatially variable patterns of succession. Ecology 65: 1918-1935

Thompson, K., Grime, J. P. (1979). Seasonal variation in the seed banks of herbaceous species in ten contrasting habitats. J. Ecol. 67: 893-921

Vadas, R. L., Miller, S. L., Botis, C. M., Bacon, L., Wright, W. (1982). Population dynamics of Ascophyllum nodosum: factors influencing recruitment of germlings. Abstract, First International Phycological Congress, Newfoundland, Canada, 51

Van der Pijl, L. (1982). Principles of dispersal in higher plants. Springer, New York

Vandermeulen, H., Dewreede, R. E. (1986). The phenology, mortality, dispersal and canopy species interaction of Colpomenia peregrina (Sauv.) Hamel in British Columbia. J. exp. mar. Biol. Ecol. 99: 31-47

Zechman, F. W., Mathieson, A. C. (1985). The distribution of seaweed propagules in estuarine, coastal and offshore waters of New Hampshire, USA. Botanica mar. 28: 283-294 